\title{
The Use of Mineral Trioxide Aggregate in The Treatment of Horizontal Root Fractures: A Case Presentation and Literature Update
}

\author{
Elif Ballıkaya(0000-0002-1743-1881) ${ }^{\alpha}$, Hamdi Cem Güngör(0000-0001-7675-9265) ${ }^{\beta}$
}

Selcuk Dent J, 2021; 8: 850-858 (Doi: 10.15311/selcukdentj.788282)

Başvuru Tarihi: 01 Eylül 2020 Yayına Kabul Tarihi: 18 Ocak 2021

\begin{abstract}
The Use of Mineral Trioxide Aggregate in The Treatment of Horizontal Root Fractures: A Case Presentation and Literature Update

Root fracture is a rarely seen traumatic injury in permanent dentition. Its prevalence is between 0.5 and $7 \%$. Tooth survival is significantly affected by the type of healing and the location of the root fracture. Additionally, the patient's age, stage of root development, mobility and dislocation of the coronal fragment, and diastasis between fragments are the important factors following this kind of injuries.

This case report was aimed to present the treatment of horizontal root fracture with MTA plug and 6-year follow-up results. A literature update regarding the use of MTA in the management of horizontal root fractures was also added to discuss its merit.
\end{abstract}

\section{KEYWORDS}

Horizontal root fracture, Root canal treatment, Mineral trioxide aggregate, Apical plug

A root fracture is an uncommon type of traumatic dental injury in permanent dentition. Its prevalence ranges from $0.5 \%$ to $7 \%{ }^{1}$ and occurs more frequently in the 11- to 20-year-old age group. ${ }^{2}$ The most common etiological factors are fight and foreign bodies striking the teeth. As in other dental trauma cases, maxillary central incisors are frequently affected. A root fracture could be horizontal, oblique, or vertical. However, horizontal and oblique root fractures are more commonly observed. ${ }^{3}$ The injury usually damages the middle-third of the root, while the coronal- and apical-third fractures exist in relatively fewer incidents. Cervical root fractures have the worst prognosis due to reduced stability of the coronal fragment and loss of vitality. ${ }^{4}$

In clinical examination, this type of injury can be viewed as an extrusive luxation in palatal direction. The tooth may present extreme mobility, which is closely related to the location of the fracture and the diastasis between fragments. ${ }^{5}$ Differential diagnosis is made by a radiographic examination. The International Association of Dental Traumatology (IADT) guidelines recommend a periapical radiograph

\section{ÖZ}

Horizontal Kök Kırıklarının Tedavisinde Mineral Trioksit Agregat Kullanımı: Olgu Sunumu ve Literatür Güncellemesi

Kök kırığı, kalıcı dişlenme döneminde nadir görülen travmatik diş yaralanması çeşididir. Prevalansı \% 0,5 ve 7 arasında değişmektedir. Dişin sağ kalımı iyileșmenin türü ve kök kırığının konumundan önemli ölçüde etkilenmektedir. Ayrıca, hastanın yaşı, kök gelişiminin evresi, koronal parçanın mobilitesi ve yer değiştirmesi, koronal parçalar arasında boşluk olması bu yaralanmaları takiben diğer önemli faktörler arasındadır.

Bu olgu sunumunda, horoizontal kök kırığının MTA tıkaç ile tedavisi ve 6 yıllık takibinin sunulması amaçlanmıştır. Horizontal kök kırıklarının tedavisinde MTA kullanımına ilişkin literatür güncellemesi de MTA'nın önemini tartışmak için eklenmiştir.

\section{ANAHTAR KELIMELER}

Horizontal kök kırığı, kök kanal tedavisi, mineral trioksid agregatı, apikal tıkaç

taken with parallel technique and multiple occlusal projections with different vertical angulations. However, in cases where these radiographs do not provide sufficient information for treatment planning, the central beam have been recommended to increase the diagnostic precision in root fractures. ${ }^{5,6}$

The treatment protocol for root fractures comprises repositioning of the coronal fragment, if displaced, and immobilizing the tooth for short term (4 weeks) with a non-rigid splint. ${ }^{6}$ Andreasen et al. ${ }^{7}$ have reported that ideal repositioning of root fractures with a dislocated coronal fragment of up to $1 \mathrm{~mm}$ favored both healing with hard tissue and also reduced the risk of possible pulp necrosis. Besides; the patient age, level of root development, mobility, dislocation of the coronal fragment, and diastasis between fragments have been stated to have an important effect on the prognosis and recovering of root fractures. $^{8}$ Pulp necrosis is seen in $5-25 \%$ of rootfractured teeth. ${ }^{1}$ When root-fracture was observed, root canal treatment of the coronal section should be initiated.

\footnotetext{
${ }^{\alpha}$ Hacettepe University, Faculty of Dentistry, Department of Pediatric Dentistry, Ankara, Turkey

${ }^{\beta}$ Marquette University, School of Dentistry, Department of Developmental Sciences Division of Pediatric Dentistry, Milwaukee WI, USA
} 
This case report aims to present the treatment and 6year follow-up of maxillary left central incisor with horizontal root fracture. In addition, the use of MTA in the treatment of root fractures is intended to be discuss in light of the recent literature.

\section{CASE REPORT}

A 13-year-old boy was referred to the pediatric dentistry clinics one day after a fall accident at school. The patient had an unremarkable medical history. He reported pain and increased sensitivity due to the mobility of his front tooth, which occurred following the accident. Intraoral examination revealed extruded, and palatally displaced maxillary left central incisor which was tender to palpation and percussion. An uncomplicated crown fracture of maxillary right central incisor was also noted. Radiographic examination showed a horizontal root fracture in the middle third of tooth maxillary left central incisor with a diastasis greater than $3 \mathrm{~mm}$. It was also observed that the apices of affected teeth were completely formed (Figure 1).

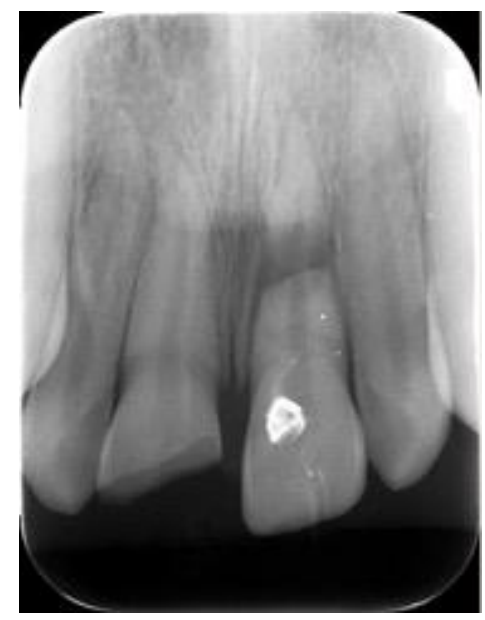

Figure 1.

Preoperative periapical radiograph

The coronal fragment of maxillary left central incisor was gently repositioned by using finger pressure. A radiograph was taken to verify its positioning (Figure 2 ).

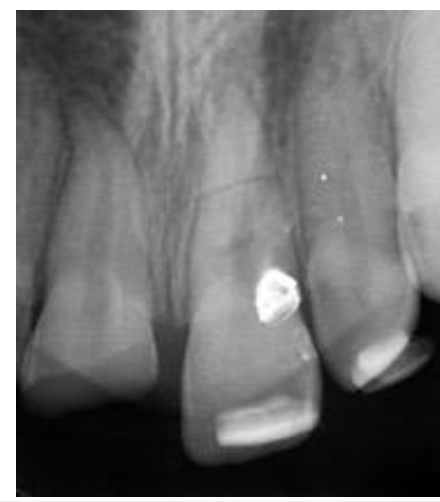

Figure 2.

Periapical radiograph showing repositioning of the fractured root
A semi-rigid splint made from $0.9 \mathrm{~mm}$ monofilament fishing line and composite resin was applied to teeth (from maxillary left central incisor to maxillary left canine). Crown fractured maxillary right central incisor was temporarily restored with glass ionomer cement. Along with regular oral hygiene instructions, the patient was recommended a soft diet and $0.12 \%$ chlorhexidine rinse for ten days.

A week later, the patient referred with increased pain on tooth maxillary left central incisor. The tooth was extremely tender to palpation and percussion. Upon confirmation of irreversible pulpitis with electrical and cold tests, endodontic treatment of the coronal fragment was planned. Following administration of local anesthesia, the pulp was accessed and the necrotic pulp was removed. Using the radiograph taken as a guidance, a $\mathrm{K}$ file was inserted into the root canal. Another radiograph was taken and the working length was determined. The root canal was prepared with Gates-Glidden drills. The care was taken to keep the file tip within the coronal fragment to avoid damaging the pulp in the apical fragment. Irrigations with $2.25 \%$ sodium hypochlorite and sterile saline were followed by placement of calcium hydroxide dressing into the canal. The access cavity was temporarily restored with glass ionomer cement.

Four weeks later, calcium hydroxide dressing was changed in maxillary left central incisor and the splint was removed. The tooth had class II mobility. The patient had quite poor oral hygiene and no improvement in hygiene was present although he was motivated in first appointment. At the second-month visit, due to continuing symptoms, calcium hydroxide paste was reapplied and the importance of oral hygiene was stressed. In the same appointment, the patient reported no discomfort with maxillary right central incisor which responded positively to vitality tests. A definitive restoration of the tooth was made with composite resin using an etch-and-rinse adhesive.

At three months postoperatively, maxillary right central incisor was observed to be asymptomatic. It was decided to place an apical plug to the coronal fragment. To this end, mineral trioxide aggregate (ProRoot MTA, Tulsa Dental Products, Tulsa, OK, USA) paste was prepared with 1:3 ratio (powder/liquid) as per the manufacturer's instructions. A root canal messing gun (Dentsply Maillefer, Ballaigues, Switzerland) was used to transport and incrementally place the paste into the root canal. An endodontic plugger with a stopper placed $1 \mathrm{~mm}$ behind the working length was used to adapt and obtain a 3-mm thick MTA plug over the fracture line, which was verified with periapical radiographs (Figure 3). 


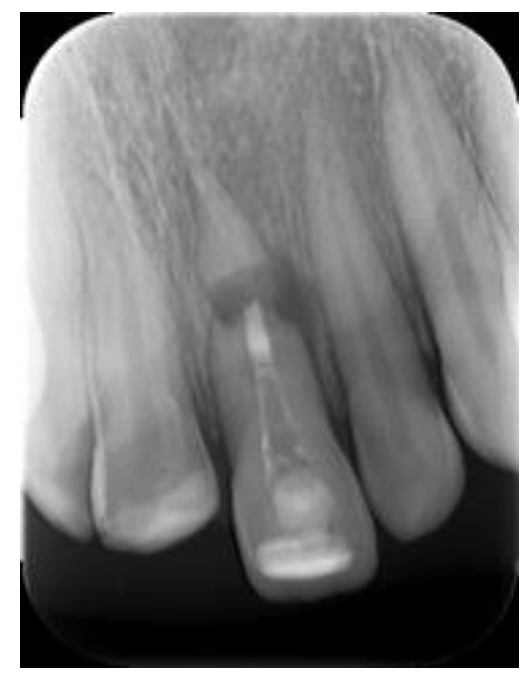

Figure 3.

MTA plug over the fracture line

A 2-mm glass ionomer cement was placed over the MTA plug, and the remaining coronal portion of the crown was restored with incremental layers of composite resin (Filtek Z250, 3M ESPE, Seefeld, Germany) incorporating an etch-and-rinse adhesive (Single Bond, 3M ESPE, Seefeld, Germany).

Clinical examinations continued at six-month intervals, while radiographic observations were made once a year. Periapical radiolucency surrounding the fracture line decreased over time (Figure 4).

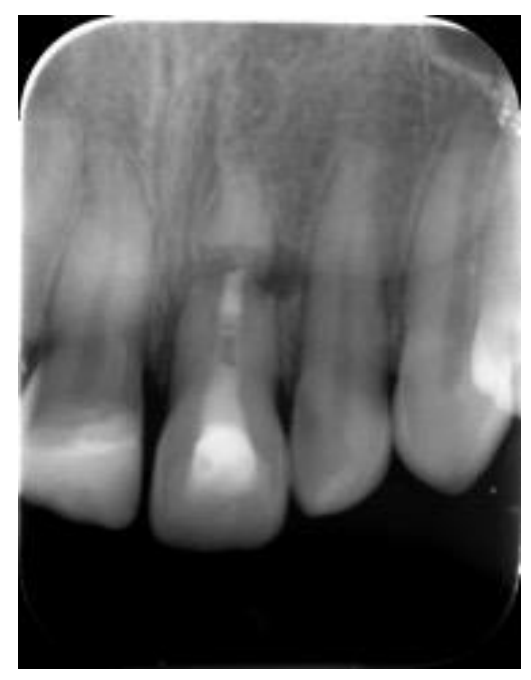

Figure 4.

Radiograph at the $3^{\text {rd }}$ year control

Radiographic evidence of periradicular healing with interposition of hard tissue was evident on the control radiograph taken at six-year visit (Figure 5). Clinically, the tooth was free of symptoms with optimal gingival health. The mobility of the tooth was within physiological limits.

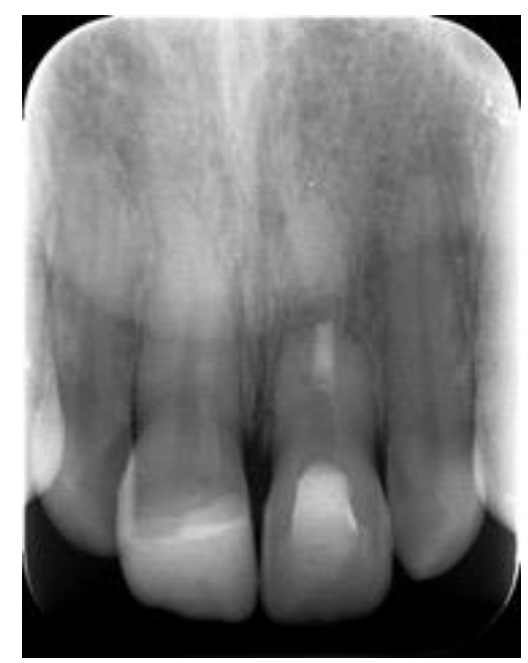

Figure 5.

Radiograph at the 6th year control shows satisfactory healing around the fractured root with healthy alveolar bone trabeculation Also note complete obliteration of the apical fragment

\section{DISCUSSION}

A root fracture is a complex type of dental injury, which damages the pulp, dentin, and periodontium. The diagnosis and timely intervention may significantly affect prognosis. ${ }^{5}$ Nevertheless, the prognosis could be complicated due to the preinjury and injury factors. These may be the patient's age, level of root development, the location of the fracture, the mobility of coronal fragment, and diastasis between fragments. ${ }^{1,8}$ The age and level of root development determine the size of the pulpal lumen at the fracture site. Hence, they are also significant factors for healing (i.e., good vascularity and the high number of cells). ${ }^{8,9}$ On the other hand, dislocation and/or mobility of the coronal fragment may lead to diastasis between the apical and coronal fragments. This results in the rupture or stretching of the pulp at the fracture site.

Repositioning and splinting are key factors for protecting the pulp when increased mobility of the coronal fragment is likely to impose further damage. The chances of both pulp healing and hard tissue repair in immature and mature teeth significantly reduce without optimal repositioning. ${ }^{7,9}$ Increased millimeter diastasis between fragments has been shown to progressively worsen healing. ${ }^{8}$ However, when initial displacement did not exceed $1 \mathrm{~mm}$, ideal repositioning has been shown to significantly increase the possibility of both pulpal healing and hard tissue repair. ${ }^{7}$ Splinting time depends on the level of the fracture. A passive and flexible splint for 4 weeks is necessary for root fractures except for the cervical fractures may require a longer period of time up to 4 months. ${ }^{6}$ 
The International Association of Dental Traumatology (IADT) guidelines suggest using flexible splints for stabilization of the traumatized teeth. ${ }^{6}$ The type, length or dimension of splints have influence on the rigidity of splint. The functional movement of the traumatized teeth could be provided by a flexible splint compared to a rigid one. Hence, the risk of ankylosis can be prevented. ${ }^{10,11}$ According to the study conducted by Kwan et.al, ${ }^{10}$ monofilament nylon composite splint, stainless steel or nickel titanium wires up to $0.4 \mathrm{~mm}$ diameter were significantly more flexible than direct composite splints. In the present case the splint made from $0.9 \mathrm{~mm}$ monofilament fishing line was preferred due to the condition that it was the only available option in the clinic at that time. Although this might have posed a concern, no ankylosis or other adverse events occurred during entire follow-up period. The splint was observed to allow for physiological mobility of the teeth which is essential for splinting of dental trauma cases as suggested by Andreasen et al. ${ }^{12}$

As per the evidence, prescription of antibiotics and/or anti-inflammatory drugs is not recommended, unless dictated by the patient's general condition. ${ }^{2,7}$ The pain, should also be managed by reasonable medication.

The vitality of the pulp and the type of healing (or nonhealing) occurring on the fracture line strongly determines the prognosis of horizontal root fractures. Healing may take place by the interposition of hard tissue $(\mathrm{HT})$, or by the interposition of the connective tissue (CT). The interposition of granulation tissue (GT) at the fracture site is also possible. It is a response to the necrotic coronal pulp, which becomes infected by bacterial invasion of the initial rupture site in the periodontal ligament (PDL). ${ }^{13}$ Unless the infection of coronal fragment is eliminated; healing is not possible. ${ }^{14,15}$ It has been reported that GT never occurred in teeth with open apices. ${ }^{2}$

The location of fracture and the type of healing are also related to the long-term tooth survival following horizontal root fractures. ${ }^{16}$ Root fractures in the apical and middle third usually heal spontaneously, while the fractures in the cervical area have diminished chances for healing..$^{17,18}$ The study by Andreasen et al. ${ }^{16}$ has evidenced the effect of type of healing on tooth survival. According to the authors, the location of fracture did not seem to result in tooth loss if the teeth healed with $\mathrm{HT}$. If CT healing occurred, the estimated 8-year survival rates of apical, mid-root, and cervicalmid-root fractures were all significantly higher than those of cervical fractures. For non-healing teeth due to interposition of GT, the location of fracture had a considerable effect on tooth loss. ${ }^{16}$

The patients with root fracture should be followed clinically and radiologically for 5 years. ${ }^{6}$ Symptoms of pulp necrosis appear within the first 3 months after injury. ${ }^{2}$ Root canal treatment is not indicated injury. ${ }^{2}$ Root canal treatment is not indicated immediately following a horizontal root fracture until the objective signs of pulp necrosis are confirmed

After a dental traumatic injury, discoloration may happen due to an increase in venous blood and accumulated metabolites. Most discolorations occur within 2-3 days after injury and may reverse/resolve within 4-8 weeks. $^{19}$ The discoloration disappears after revascularization is completed, the metabolites in the pulp chamber and dentinal tubules are disintegrated. Other clinical signs like pain, vestibule swelling, resorption, or lesion should be considered for pulpal necrosis. Oneyear follow-up is recommended after horizontal root fractures for the complete self-repair of the pulp. ${ }^{20}$ It has also been shown that, if pulp necrosis happened, the apical fragment frequently would maintain its vitality. ${ }^{21}$ Therefore, endodontic treatment is only recommended for coronal fragment only.

The control of infection in the root canal becomes extremely important when the pulp is no longer vital. As mentioned above, the condition leads to the interposition of GT, which is considered non-healing. It is characterized by radiographic loss of lamina dura, increased rarefaction and widening of the fracture line, along with clinical signs and symptoms of pulpal necrosis.

Due to its disinfecting and hard-tissue inducing properties, calcium hydroxide is a widely used material for intracanal dressing. It provides a suitable environment for hard tissue barrier formation (i.e. osteocementum) at the apical end of the coronal fracture, similar to the obtained in apexification procedures. ${ }^{22,23}$ Cvek et al. ${ }^{23}$ have tested the benefit of using calcium hydroxide in the treatment of rootfractured teeth with non-vital coronal fragments. In the first group, the root canal filling with gutta-percha (GP) was performed only in the coronal fragment. The second group comprised the root canal filling of coronal and apical fragments with gutta-percha. In the third group, the coronal fragment was filled with gutta-percha, and the apical fragment was surgically removed. Root-fractured teeth whose coronal fragments were treated with calcium hydroxide, and then filled with GP comprised group 4 . In the fifth group, the exposed pulps of vital teeth with concomitant root and crown fractures were managed by partial pulpotomy. The highest frequency of periodontal healing was found in the fourth group. This finding led the authors to conclude that the choice of treatment for rootfractured non-vital teeth was calcium hydroxide dressing followed by gutta-percha filling.

For decades, calcium hydroxide has been a cornerstone of treatment plans for most of the dental trauma cases, including root fractures. ${ }^{13}$ However, 
due to a number of clinical and experimental studies that have reported increased risk of cervical root fracture, its repeated and long-term use as an intracanal dressing has been questioned. ${ }^{24-28}$ In clinical studies by $\mathrm{Cvek}^{24}$ and Al-Jundi ${ }^{26}$, the incidence of cervical fracture has been reported to be $40 \%$ and $32 \%$, respectively. Similarly, in an vitro study; permanent human incisor teeth exhibited reduced microtensile fracture strength of by $23.0 \%$ to $43.9 \%$ when root canals were filled with calcium hydroxide after 7 to 84 days, respectively. ${ }^{28}$ Andreasen et al. ${ }^{25}$ have also indicated that the fracture strength of immature sheep teeth was halved in about a year related to the root filling with calcium hydroxide. The authors have discussed the mechanisms that might involve in the weakening of root dentin by the longterm use of calcium hydroxide. The suggested mechanism was mainly attributed to the $\mathrm{pH}$ alterations in dentin occurred after calcium hydroxide treatment. ${ }^{29}$ It has also been shown that treatment with calcium hydroxide reduced the flexural strength of dentin. ${ }^{30}$ The dentin which comprises collagen network and hydroxyapatite crystals may be disrupted due to neutralization, dissolution, or denaturizing of acid proteins and proteoglycans by calcium hydroxide. ${ }^{25}$ The effect of these interactions may lead to decreased organic support and mechanical properties in dentin structure. Altogether, the findings underline the need for precautionary measures to limit the long-term use of calcium hydroxide in order to avoid cervical root fractures, particularly in children with traumatized immature teeth. ${ }^{25}$

In the presented case, $\mathrm{CH}$ was kept in the root canal for about three months due to continuing symptoms of the patient. No cervical fracture was observed related to this approach. The complete root formation and the presence of adequate cervical root dentin might have contributed to this which was also suggested by Kahler et al. ${ }^{31} \mathrm{He}$ argued that the level of root development rather than the long-term use of calcium hydroxide might be more relevant to root fracture. While the area and the issue need further research to reach a sound conclusion, the search for alternative(s) to calcium hydroxide are well underway. ${ }^{32}$ Among those, mineral trioxide aggregate (MTA) appeared to be the most promising ${ }^{27}$ due to its chemical and physical properties. ${ }^{33}$

The effects of $\mathrm{CH}$ and MTA on the root dentin's fracture resistance were evaluated by Andreasen et al. ${ }^{27}$ who carried out a study on sheep teeth to test the differences. They reported a significant decrease in fracture resistance (a) of $\mathrm{CH}$-treated root canals after 100 days, compared to (b) roots stored in saline only and (c) roots treated with $\mathrm{CH}$ for 30 days and then filled with MTA, and (d) roots filled with MTA. They concluded that keeping $\mathrm{CH}$ in the root canal for only 30 days, followed by filling with MTA resulted in no significant decrease in fracture strength of the root within an observation period of 100 days. Another study found that the fracture strengths of MTA-filled immature roots did not significantly differ from untreated or $\mathrm{CH}$-treated roots at two weeks or two months. However, after one year, the strengths in MTA group was reported to be significantly higher when compared to other two groups. ${ }^{33}$ The authors suggested that the induced expression of tissue inhibitor of metalloproteinase-2 (TIMP-2) in the dentin matrix by MTA might have prevented destruction of the collagen matrix.

MTA is a bioactive material that provides an optimum environment for healing upon direct contact with human tissues. ${ }^{34,35}$ Although more studies are needed to reveal the clear mechanism of action responsible for the following abilities, MTA

1. Creates calcium hydroxide $(\mathrm{CH})$ that releases calcium ions for cell attachment and proliferation $^{36-39}$

2. Generates an antibacterial environment due to its alkaline $\mathrm{pH}^{40,41}$

3. Modulates cytokine production ${ }^{42-44}$

4. Promotes differentiation and migration of hard tissue-producing cells ${ }^{45,46}$

5. Forms hydroxyapatite HA (or carbonated apatite) on the surface of MTA and supplies a biologic seal. ${ }^{36,37,47}$

In case of a root fracture, the coronal fragment could be considered as a tooth with an open apex and whether an adequate crown: root ratio is present should be considered. ${ }^{48}$ For a successful outcome, closure of the open apex with a biocompatible material, and subsequent guttapercha obstruction are essential. ${ }^{18,32,49}$ With its properties cited above, MTA seems to be an ideal material that can be used as a fracture line plug in horizontal root fractures. However, the number of studies in the literature regarding the use of MTA for this purpose is minimal. Also, there are not many case reports presenting the long-term follow-up of such cases, especially in children. ${ }^{18,50-55}$

Radiograph at the sixth year control of the present case shows complete obliteration of the apical fragment. Pulp canal obliteration is a common occurrence in root fractures and should be viewed as a reaction of vital pulp to trauma. ${ }^{2}$ Pulp necrosis of apical fragment is extremely rare in cases of root fracture. ${ }^{56}$ It can only be confirmed radiologically, since pulp sensitivity tests are unreliable. ${ }^{23}$ Endodontic treatment of coronal fragment along with the surgical removal of infected apical fragment is suggested in these cases, since sufficient sealing of root canal in the apical fragment is not feasible by conventional endodontics. ${ }^{23}$ 
There is only one study in the literature that presented the healing outcome of intra-alveolar root fractures treated with MTA. Kim et al. ${ }^{57}$, in a retrospective study, evaluated 19 of 22 root-fractured teeth. Seventeen teeth $(89.5 \%)$ have showed healing. In 7 teeth $(36.8 \%)$, root fracture healed with calcified tissue, while 8 teeth (42.1\%) exhibited interposition of connective tissue. The interposition of connective tissue and bone took place in 2 teeth (10.5\%), while 2 teeth (10.5\%) exhibited interposition of granulation tissue and did not heal. Since this study was carried out in an adult population, more studies that focus on root fractures in children treated with MTA is warranted.

Some existing disadvantages of MTA such as discoloration potential, difficulty in handling, and long setting time should also be mentioned. Although several calcium silicate-based materials such as bioactive endodontic cements (BECs), calciumenriched mixture (CEM) cement, Biodentine, BioAggregate, BioRoot RCS, have been developed to manage these inconveniences ${ }^{58}$, there is only one case report root fracture presenting the use of BECs with a relatively short follow-up period..$^{59}$

In the presented case, the fracture line was sealed with an MTA plug over which a composite restoration was made following the placement of a glass-ionomer cement base. However, these applications were preceded by a temporary dressing of the canal with $\mathrm{CH}$ for a total duration of three months. Due to the patient's persisting symptoms, $\mathrm{CH}$ was kept in the root canal and was changed twice during this period. After six years, the tooth showed no discoloration, presented optimal gingival health and had mobility within physiological limits. The new hard tissue formation in the fracture line, periodontal healing and lamina dura surrounding the fragments were also evident in the sixth-year follow-up radiograph.

\section{CONCLUSION}

- The immediate treatment of teeth with horizontal root fractured and displaced coronal fragment is important for the probability of favorable outcomes.

- Clinical and radiological follow-up of root fractures for five years is important to ensure a complete healing.

- MTA is a biocompatible material that can be used as a fracture line plug in horizontal root fractures. 


\section{REFERENCES}

1. Andreasen FM, Andreasen $\mathrm{JO}$ and Tsilingaridis $\mathrm{G}$. Root Fractures. In: Andreasen JO, Andreasen FM and Andersson L (eds). Textbook and Color Atlas of Traumatic Injuries to The Teeth. 5th ed. Oxford: Wiley Blackwell, 2019, pp.377-412.

2. Andreasen FM, Andreasen $\mathrm{JO}$ and Bayer $\mathrm{T}$. Prognosis of root-fractured permanent incisors-prediction of healing modalities. Endod Dent Traumatol 1989; 5: 11-22.

3. Majorana A, Pasini S, Bardellini E, et al. Clinical and epidemiological study of traumatic root fractures. Dent Traumatol 2002; 18: 77-80.

4. Cvek M, Tsilingaridis $G$ and Andreasen JO. Survival of 534 incisors after intra-alveolar root fracture in patients aged 7-17 years. Dent Traumatol 2008; 24: 379-387.

5. Molina JR, Vann Jr WF, Mclntyre JD, et al. Root fractures in children and adolescents: diagnostic considerations. Dent Traumatol 2008; 24: 503-509.

6. Bourguignon $\mathrm{C}$, Cohenca N, Lauridsen $\mathrm{E}$, et al. International Association of Dental Traumatology guidelines for the management of traumatic dental injuries: 1. Fractures and luxations. Dent Traumatol 2020; 36: 314-330.

7. Andreasen JO, Andreasen FM, Mejare I, et al. Healing of 400 intra-alveolar root fractures. 2. Effect of treatment factors such as treatment delay, repositioning, splinting type and period and antibiotics. Dent Traumatol 2004; 20: 203-211.

8. Andreasen JO, Andreasen FM, Mejare I, et al. Healing of 400 intra-alveolar root fractures. 1. Effect of pre-injury and injury factors such as sex, age, stage of root development, fracture type, location of fracture and severity of dislocation. Dent Traumatol 2004; 20: 192-202.

9. Cvek M, Andreasen JO and Borum MK. Healing of 208 intra-alveolar root fractures in patients aged 717 years. Dent Traumatol 2001; 17: 53-62.

10. Kwan SC, Johnson JD and Cohenca N. The effect of splint material and thickness on tooth mobility after extraction and replantation using a human cadaveric model. Dent Traumatol 2012; 28: 277 281.

11.Berthold C, Auer FJ, Potapov S, et al. Influence of wire extension and type on splint rigidityevaluation by a dynamic and a static measuring method. Dent Traumatol 2011; 27: 422-431.

12. Andreasen $\mathrm{JO}$ and KS. O. Splinting of traumatized teeth. In: Andreasen JO, Andreasen FM and Andersson L (eds). Textbook and Color Atlas of Traumatic Injuries to the Teeth. 5th ed. Oxford: Wiley Blackwell, 2019, pp.962-971.

13. Andreasen JO, Bakland LK, Flores MT, et al. Traumatic Dental Injuries: A Manual. 3rd ed. Oxford, United Kingdom: Wiley-Blackwell, 2011.
14.Trope M, Barnett F, Sigurdsson A, et al. The role of endodontics after dental traumatic injuries. In: Hargreaves KM and Berman LH (eds) Cohen's Pathways of The Pulp. 11th ed.: Mosby, 2015, pp.758-792.

15.Diangelis AJ, Andreasen JO, Ebeleseder KA, et al. International Association of Dental Traumatology guidelines for the management of traumatic dental injuries: 1. Fractures and luxations of permanent teeth. Dent Traumatol 2012; 28: 2-12.

16. Andreasen JO, Ahrensburg SS and Tsilingaridis G. Root fractures: the influence of type of healing and location of fracture on tooth survival rates - an analysis of 492 cases. Dent Traumatol 2012; 28: 404-409.

17.Duggan D, Quinn F and O'Sullivan M. A long-term follow up of spontaneously healed root fractures later subjected to orthodontic forces-two case reports. Dent Traumatol 2008; 24: 231-234.

18. Kusgoz A, Yildirim T, Tanriver M, et al. Treatment of horizontal root fractures using MTA as apical plug: report of 3 cases. Oral Surg Oral Med Oral Pathol Oral Radiol 2009; 107: e68-e72.

19.Dahl JE KS, Pallesen U. Bleaching of the discolored traumatized tooth. In: Andreasen JO AF, Andersson L (ed). Textbook and Color Atlas of Traumatic Injuries to the Teeth. 5th ed. Oxford: Wiley Blackwell, 2019, pp.972-981.

20. Liao Q, Ye W, Yue J, et al. Self-repaired process of a traumatized maxillary central incisor with pulp infarct after horizontal root fracture monitored by laser doppler flowmetry combined with tissue oxygen monitor. J Endod 2017; 43: 1218-1222.

21. Andreasen $\mathrm{JO}$ and Hjorting-Hansen E. Intraalveolar root fractures: radiographic and histologic study of 50 cases. J Oral Surg 1967; 25: 414-426.

22. Waterhouse PJ and Whitworth JM. Pediatric endodontics: Endodontic treatment for the primary and young permanent dentition. In: Hargreaves KM and Berman LH (eds). Cohen's Pathways of The Pulp. 11th ed., 2015, pp.e1-e44.

23. Cvek M, Mejare I and Andreasen JO. Conservative endodontic treatment of teeth fractured in the middle or apical part of the root. Dent Traumatol 2004; 20: 261-269.

24.Cvek M. Prognosis of luxated non-vital maxillary incisors treated with calcium hydroxide and filled with gutta-percha. A retrospective clinical study. Endod Dent Traumatol 1992; 8: 45-55.

25.Andreasen JO, Farik B and Munksgaard EC. Longterm calcium hydroxide as a root canal dressing may increase risk of root fracture. Dent Traumatol 2002; 18: 134-137.

26. Al-Jundi SH. Type of treatment, prognosis, and estimation of time spent to manage dental trauma in late presentation cases at a dental teaching hospital: a longitudinal and retrospective study. Dent Traumatol 2004; 20: 1-5. 
27.Andreasen JO, Munksgaard EC and Bakland LK. Comparison of fracture resistance in root canals of immature sheep teeth after filling with calcium hydroxide or MTA. Dent Traumatol 2006; 22: 154-

28. Rosenberg B, Murray PE and Namerow K. The effect of calcium hydroxide root filling on dentin fracture strength. Dent Traumatol 2007; 23: 26-29.

29. Nerwich A, Figdor D and Messer HH. pH changes in root dentin over a 4-week period following root canal dressing with calcium hydroxide. J Endod 1993; 19: 302-306.

30.Grigoratos D, Knowles $\mathrm{J}, \mathrm{Ng} \mathrm{YL}$, et al. Effect of exposing dentine to sodium hypochlorite and calcium hydroxide on its flexural strength and elastic modulus. Int Endod J 2001; 34: 113-119.

31.Kahler SL, Shetty S, Andreasen FM, et al. The effect of long-term dressing with calcium hydroxide on the fracture susceptibility of teeth. J Endod 2018; 44: 464-469.

32.Camilleri J, Montesin FE, Papaioannou S, et al. Biocompatibility of two commercial forms of mineral trioxide aggregate. Int Endod J 2004; 37: 699-704.

33. Hatibovic-Kofman S, Raimundo L, Zheng L, et al. Fracture resistance and histological findings of immature teeth treated with mineral trioxide aggregate. Dent Traumatol 2008; 24: 272-276.

34.Parirokh $M$ and Torabinejad $M$. Mineral trioxide aggregate: a comprehensive literature review--Part III: Clinical applications, drawbacks, and mechanism of action. J Endod 2010; 36: 400-413.

35.Torabinejad $\mathrm{M}$, Parirokh $\mathrm{M}$ and Dummer $\mathrm{PMH}$. Mineral trioxide aggregate and other bioactive endodontic cements: an updated overview - part II: other clinical applications and complications. Int Endod J 2018; 51: 284-317.

36.Sarkar NK, Caicedo R, Ritwik $P$, et al. Physicochemical basis of the biologic properties of mineral trioxide aggregate. J Endod 2005; 31: 97100.

37.Bozeman TB, Lemon RR and Eleazer PD. Elemental analysis of crystal precipitate from gray and white MTA. J Endod 2006; 32: 425-428.

38. Camilleri J. Characterization of hydration products of mineral trioxide aggregate. Int Endod J 2008; 41: 408-417.

39. Ozdemir HO, Ozcelik B, Karabucak B, et al. Calcium ion diffusion from mineral trioxide aggregate through simulated root resorption defects. Dent Traumatol 2008; 24: 70-73.

40. Eldeniz AU, Hadimli $\mathrm{HH}$, Ataoglu $\mathrm{H}$, et al. Antibacterial effect of selected root-end filling materials. J Endod 2006; 32: 345-349.

41. Fridland $M$ and Rosado R. MTA solubility: a long term study. J Endod 2005; 31: 376-379.

42. Guven G, Cehreli ZC, Ural A, et al. Effect of mineral trioxide aggregate cements on transforming growth factor beta1 and bone morphogenetic protein production by human fibroblasts in vitro. $\mathrm{J}$ Endod 2007; 33: 447-450.
43. Huang TH, Yang CC, Ding SJ, et al. Inflammatory cytokines reaction elicited by root-end filling materials. J Biomed Mater Res B Appl Biomater 2005; 73: 123-128.

44.Abdullah D, Ford TR, Papaioannou S, et al. An evaluation of accelerated Portland cement as a restorative material. Biomaterials 2002; 23: 40014010.

45. Tecles O, Laurent $P$, Aubut V, et al. Human tooth culture: a study model for reparative dentinogenesis and direct pulp capping materials biocompatibility. J Biomed Mater Res B Appl Biomater 2008; 85: 180-187.

46. Kuratate $M$, Yoshiba $K$, Shigetani $Y$, et al. Immunohistochemical analysis of nestin, osteopontin, and proliferating cells in the reparative process of exposed dental pulp capped with mineral trioxide aggregate. J Endod 2008; 34: 970-974.

47.Reyes-Carmona JF, Felippe MS and Felippe WT. Biomineralization ability and interaction of mineral trioxide aggregate and white portland cement with dentin in a phosphate-containing fluid. $\mathrm{J}$ Endod 2009; 35: 731-736.

48. Abbott PV. Diagnosis and management of transverse root fractures. Dent Traumatol 2019; 35: 333-347.

49. Giuliani V, Baccetti $T$, Pace $R$, et al. The use of MTA in teeth with necrotic pulps and open apices. Dent Traumatol 2002; 18: 217-221.

50. Bramante CM, Menezes R, Moraes IG, et al. Use of MTA and intracanal post reinforcement in a horizontally fractured tooth: a case report. Dent Traumatol 2006; 22: 275-278.

51. Chaniotis $A$. The use of MTA/blood mixture to induce hard tissue healing in a root fractured maxillary central incisor. Case report and treatment considerations. Int Endod J 2014; 47: 989-999.

52. Choi Y, Hong SO, Lee SR, et al. Healing after horizontal root fractures: 3 cases with 2-year follow-up. Restor Dent Endod 2014; 39: 126-131.

53. Cicek E, Yilmaz N and Kocak MM. Intraradicular splinting with endodontic instrument of horizontal root fracture. Case Rep Dent 2015; 2015: 505370.

54.Erdem AP, Ozdas DO, Dincol E, et al. Case Series: root healing with MTA after horizontal fracture. Eur Arch Paediatr Dent 2009; 10: 110113.

55.Yildirim $T$ and Gençoğlu N. Use of mineral trioxide aggregate in the treatment of horizontal root fractures with a 5-year follow-up: report of a case. J Endod 2009; 35: 292-295.

56. Cvek M, Mejare I and Andreasen JO. Healing and prognosis of teeth with intra-alveolar fractures involving the cervical part of the root. Dent Traumatol 2002; 18: 57-65. 
57. Kim D, Yue W, Yoon TC, et al. Healing of horizontal intra-alveolar root fractures after endodontic treatment with mineral trioxide aggregate. $\mathrm{J}$ Endod 2016; 42: 230-235.

58. Torabinejad M, Parirokh $\mathrm{M}$ and Dummer P. Mineral trioxide aggregate and other bioactive endodontic cements: an updated overview-part II: other clinical applications and complications. International endodontic journal 2018; 51: 284-317.

59. Asgary S, Mirmohammadi $\mathrm{H}$ and Parhizkar A. Management of Symptomatic Horizontal Mid-root Fractures after Unsuccessful Orthograde Endodontic Retreatments. Cureus 2019; 11: 5473.

Corresponding Author:

\section{Elif BALLIKAYA}

Hacettepe University,

Faculty of Dentistry

Department of Pediatric Dentistry

Ankara, Turkey

Tel : : +903123052280

E-Mail : eyildirim@hacettepe.edu.tr 